\title{
ANALISIS FAKTOR DOMINAN YANG MEMPENGARUHI PEMBERIAN KREDIT OLEH LPD DI KABUPATEN BANGLI
}

\author{
${ }^{1}$ I Nengah Suarmanayasa, ${ }^{2}$ I Wayan Suwendra, ${ }^{3}$ Gede Putu Agus Jana Susila \\ 1,2,3 Jurusan Manajemen, Fakultas Ekonomi dan Bisnis \\ Universitas Pendidikan Ganesha \\ Singaraja, Indonesia \\ e-mail:arman_banker@yahoo.co.id
}

\begin{abstract}
Abstrak
LPD sebagai lembaga intemediasi bertugas untuk menghimpun dana dari masyarakat dan menyalurkan kembali dana tersebut kepada masyarakat dalam bentuk kredit. Kegiatan pemberian kredit merupakan kegiatan utama sebuah LPD, dimana pemberian kredit adalah tulang punggung kegiatannya. Bagi LPD, kredit adalah aset yang akan menghasilkan pendapatan bunga. Bagi dunia usaha, kredit dari LPD merupakan tambahan modal untuk kegiatan produksi dan pengembangan usaha agar tetap bisa bersaing dengan perusahaan lainnya. Bagi pemerintah, semakin banyak kredit yang mampu disalurkan oleh LPD akan semakin baik karena hal itu menunjukkan adaya peningkatan pembangunan di berbagai sektor. Besar kecilnya jumlah kredit yang mampu disalurkan oleh pihak LPD tentunya dipengaruhi oleh berbagai faktor, tetapi dalam penelitian ini hanya diteliti beberapa faktor, diantaranya : tabungan, deposito, dan modal LPD.

Penelitian ini menggunakan data dari tahun 2007 - 2011 dalam bentuk data bulanan yang diperoleh dari PT Bank BPD Cabang Bangli dan PLPDK Bangli. Metode pengumpulan data yang dipergunakan adalah metode dokumentasi, selanjutnya dilakukan analisis data dengan model regresi linear berganda. Adapun hasil dari penelitian ini adalah 1) secara simultan variabel tabungan, deposito dan modal berpengaruh signifikan terhadap pemberian kredit oleh LPD di kabupaten Bangli, 2) secara parsial variabel tabungan, deposito dan modal berpengaruh positif signifikan terhadap pemberian kredit oleh LPD di kabupaten Bangli, 3) faktor dominan yang mempengaruhi pemberian kredit adalah modal LPD.
\end{abstract}

Kata kunci : Deposito, modal LPD, Pemberian kredit dan tabungan

\begin{abstract}
LPD as an intermediation body has a significant role in collecting public's funds and distributing those funds to parties in need of fund in a form of loan. In addition, lending activity is a LPD's primary function and its back bone as the major source of income. Furthermore, credit considered a loan as an asset which will bring a future benefit namely, interest received. On the other hand, businesses will regard loan as a liability which they can use to top up their working capital in order to improve their business performance. For the government, the more the loan being distributed the better it is for the whole economy. This is regarded as an indication of development in several economy sectors. The amount of Loan
\end{abstract}


granted by the LPD is affected by several factors namely, savings, deposits, and LPD's capital.

This research conducted on five years historical data (2007 to 2011) extracted from PT BPD Bank branch Bangli and PLPDK Bangli. In addition, the data collection method used in this research is documentation method. Later, data analysis will be conducted with multiple regression models. The results of this research are 1) savings, deposits and capital simultaneously significantly affecting the amount of loan being given by Bangli LPDs, 2) savings, deposits and capital positive partial significantly affecting the amount of loan being given by Bangli LPDs, 3) the dominant factor affecting the credit is LPD's capital.

Keywords: Deposits, LPD's capital, credit allocation, and savings.

\section{PENDAHULUAN}

Keberadaan Lembaga Perkreditan Desa (LPD) memiliki beberapa tujuan, pertama, mendorong pembangunan ekonomi masyarakat desa melalui tabungan terarah serta penyaluran modal yang efektif. Kedua, memberantas sistem ijon, gadai gelap dan lainlain yang bisa disamakan dengan itu di daerah pedesaan. Ketiga, menciptakan pemerataan dan kesempatan kerja bagi warga pedesaan. Keempat, menciptakan daya beli dan melancarkan lalu lintas pembayaran serta pertukaran di desa. Landasan operasional LPD berpijak pada awigawig desa pekraman, yang mengedepankan ikatan kekeluargaan dan semangat gotong royong antarwarga desa pekraman.

Dari sudut pandang masyarakat, keberadaan LPD sangat membantu baik secara ekonomi maupun sosial. Secara ekonomi, masayarakat memiliki alternatif untuk menyimpan dan meminjam dana. LPD merupakan pilihan utama, karena mereka dapat meminjam dana dengan prosedur yang tidak berbelit-belit. Dampak sosial dari keberadaan LPD, tercermin dari taatnya LPD untuk menyumbangkan $20 \%$ keuntungannya untuk pembangunan desa dan $5 \%$ untuk dana sosial.

Setiap badan usaha termasuk juga LPD dalam usahanya tentu menginginkan suatu keuntungan. Keuntungan utama LPD diperoleh dari selisih antara bunga yang dikenakan pada sumber-sumber dana dengan bunga yang diterima dari alokasi dana tersebut (spread based). Untuk mencapai keuntungan yang optimal LPD harus menjalankan usahanya secara efektif, efisien dan ekonomis. Keuntungan yang dihasilkan sangat berguna bagi LPD untuk memberikan balas jasa terhadap masyarakat yang telah bersedia menyetorkan modal yang digunakan untuk mengembangkan usaha dan untuk menyalurkan dana sosial kepada lingkungannya. Berikut ini disajikan data perkembangan jumlah kredit dan laba LPD di kabupaten Bangli tahun 2004-2011. 
Tabel 1 Jumlah Kredit dan Laba LPD di Kabupaten Bangli Tahun 2004 - 2011

\begin{tabular}{|c|c|c|c|c|}
\hline Periode & Kredit & Pertumbuhan (\%) & Laba & $\begin{array}{c}\text { Pertumbuhan } \\
(\%)\end{array}$ \\
\hline 2004 & $54,583,335$ & - & $5,864,527$ & - \\
\hline 2005 & $64,953,729$ & 19.00 & $6,979,936$ & 19.02 \\
\hline 2006 & $75,452,564$ & 16.16 & $7,882,545$ & 12.93 \\
\hline 2007 & $89,666,017$ & 18.84 & $9,030,843$ & 14.57 \\
\hline 2008 & $119,298,540$ & 33.05 & $10,647,483$ & 17.90 \\
\hline 2009 & $156,701,448$ & 31.35 & $12,599,150$ & 18.33 \\
\hline 2010 & $191,101,559$ & 21.95 & $15,304,407$ & 21.47 \\
\hline 2011 & $233,066,642$ & 21.96 & $17,433,545$ & 13.91 \\
\hline
\end{tabular}

Sumber : Bank BPD Cabang Bangli tahun 2012

Berdasarkan tabel 1 dapat dilihat bahwa jumlah kredit yang disalurkan LPD berfluktuasi. Tahun 2008 terjadi peningkatan jumlah kredit sampai 33,05 $\%$, tapi setelah itu terjadi penurunan pertumbuhan kredit. Pendapatan utama LPD sangat tergantung dari besar kecilnya jumlah kredit yang disalurkan kepada masyarakat. Sama halnya dengan jumlah kredit, laba yang dihasilkan LPD dari tahun 2004 - 2011 juga berfluktuasi. Rata-rata pertumbuhan laba LPD selama kurun waktu 8 tahun sebesar 16,86\%. Pertumbuhan laba yang paling tertinggi terjadi pada tahun 2010 sebesar $21,47 \%$ dan paling tinggi terjadi tahun 2006 sebesar $12,93 \%$.

Jumlah kredit yang disalurkan kepada masyarakat diharapkan selalu meningkat setiap tahunnya, mengingat semakin besar kredit yang disalurkan maka pendapatan LPD juga akan semakin tinggi, semakin tingginya pendapatan berarti semakin kuat permodalan yang pada akhirnya akan meningkatkan kesehatan LPD. Hal terpenting dari penyaluran kredit adalah untuk membantu usaha nasabah yang memerlukan dana, baik dana investasi maupun dana untuk modal kerja. Bagi pemerintah, semakin banyak kredit yang disalurkan oleh pihak LPD, maka semakin baik, mengingat semakin banyak kredit berarti adanya peningkatan pembangunan di berbagai sektor.

Terdapat banyak faktor yang mempengaruhi keputusan LPD untuk menyalurkan kredit kepada masyarakat, seperti faktor internal dan faktor eksternal. Faktor eksternal yang dimaksud adalah Dana pihak ketiga (DPK) yang terdiri dari tabungan, dan deposito berjangka yang merupakan sumber utama untuk penyaluran kredit LPD. Semakin banyak dana yang mampu di himpun dari masyarakat maka akan meningkatkan kemampuan bank untuk menyalurkan kredit ke masyarakat. Dengan meningkatnya kemampuan dalam menyalurkan kredit maka pendapatan bank juga akan meningkat. Selain dana yang dihimpun dari masyarakat, LPD juga menggunakan modal LPD untuk menyalurkan kredit ke masyarakat. Modal sebuah LPD terdiri dari pertama, 
swadaya masyarakat dan atau urunan krama desa. Kedua, bantuan pemerintah atau sumber lain yang tidak mengikat. Ketiga, laba yang ditahan. Semakin banyak modal yang dimiliki sebuah LPD akan semakin baik, karena hal tersebut akan meningkatkan kemampuan LPD untuk menyalurkan kredit ke masyarakat.

LPD merupakan badan usaha keuangan milik desa yang melaksanakan kegiatan usaha di lingkungan desa dan untuk krama desa. Ketentuan tersebut menunjukkan bahwa LPD merupakan suatu bentuk lembaga ekonomi, yang oleh Perda diakui dan dikukuhkan dalam status hukum sebagai suatu bentuk badan usaha keuangan, dengan sifat yang bersifat khusus, karena hanya menyelenggarakan kegiatan usaha dalam wilayah desa pekraman.

Konsekuensi LPD sebagai lembaga intermediasi yang bermotivasi laba adalah menyalurkan dana dalam bentuk pinjaman (kredit). Bagi LPD, kredit adalah asset yang akan menghasilkan pendapatan bunga atau keuntungan. Karena kredit adalah asset yang menghasilkan pendapatan, maka porsi kredit dalam asset LPD sangat dominan. Dalam kondisi normal, berdasarkan pengalaman empiris, kredit bank merupakan $\pm 70 \%$ total asset sebuah bank (Mandala Manurung, 2004).

Definisi kredit menurut Undangundang Nomor 10 tahun 1998 tentang Perbankan adalah penyediaan uang atau tagihan yang dapat dipersamakan dengan itu, berdasarkan persetujuan atau kesepakatan pinjam meminjam antara bank dengan pihak lain yang mewajibkan pihak peminjam untuk melunasi utangnya setelah jangka waktu tertentu dengan jumlah bunga, imbalan atau pembagian keuntungan. Adapun unsur-unsur yang terkandung dalam pemberian suatu fasilitas kredit adalah kepercayaan, kesepakatan, jangka waktu, risiko, dan balas jasa. Tujuan utama pemberian suatu kredit antara lain : mencari keuntungan, membantu usaha nasabah, membantu pemerintah. Fasilitas kredit mempunyai suatu fungsi secara luas, antara lain : meningkatkan daya guna uang, meningkatkan peredaran dan lalu lintas uang, meningkatkan daya guna barang, sebagai alat stabilitas ekonomi, meningkatkan kegairahan usaha, dan untuk meningkatkan pemerataan pendapatan.

Prinsip-prinsip perkreditan disebut pula konsep 5C. Pada dasarnya konsep 5C ini dapat memberikan informasi mengenai itikad baik (willingness to pay) dan kemampuan membayar (ability to pay) nasabah untuk melunasi pinjaman beserta bunganya. Prinsip perkreditan tersebut adalah sebagai berikut : Character, Capacity, Capital, Collateral dan Condition of economy.

\section{METODE PENELITIAN}

Subjek dalam penelitian ini adalah 158 LPD yang ada di kabupaten Bangli sedangkan objek dari penelitian ini adalah faktor yang mempengaruhi pemberian kredit oleh LPD.

Ruang lingkup penelitian ini adalah terbatas pada pengaruh variabel tabungan, deposito dan modal LPD terhadap jumlah kredit yang diberikan LPD di kabupaten Bangli tahun 2007 sampai dengan tahun 2011.

Data yang diperlukan dalam penelitian ini adalah data sekunder yang

Jurnal IImu Sosial dan Humaniora | 344 
diperoleh dari Bank BPD cabang Bangli dan PLPDK Bangli. Dilihat dari sifatnya data yang digunakan berupa data kuantitatif yakni data yang berbentuk angka-angka seperti data jumlah kredit yang diberikan, tabungan, deposito dan modal LPD. Data tersebut adalah data bulanan tahun 2007 sampai dengan tahun 2011.

Variabel-variabel yang diperlukan dalam penelitian ini dibedakan menjadi dua kelompok yaitu :

1) Variabel terikat (dependent variabel) yaitu jumlah kredit yang diberikan.

2) Variabel bebas (indefendent variabel) yang terdiri atas tabungan, depsoito dan modal LPD

Adapun definisi operasional dari masing-masing variabel adalah sebagai berikut :

1) Jumlah kredit yang diberikan adalah kredit yang disalurkan untuk penggunaan investasi, modal kerja dan konsumsi pada LPD kabupaten Bangli, berdasarkan data bulanan, tahun 2007 sampai dengan tahun 2011 dalam satuan milyar rupiah.

2) Tabungan adalah simpanan masyarakat yang terdiri dari tabungan wajib dan tabungan sukarela yang penarikannya dapat dilakukan sewaktu-waktu dengan syarat tertentu, berdasarkan data bulanan tahun 2007 sampai dengan tahun 2011 dalam satuan milyar rupiah.

3) Deposito adalah simpanan masyarakat yang penarikannya hanya dapat dilakukan pada waktu tertentu sesuai perjanjian antara nasabah dengan LPD, berdasarkan data bulanan tahun 2007 sampai dengan tahun 2011 dalam satuan milyar rupiah.

4) Modal LPD adalah modal yang terdiri dari swadaya masyarakat dan atau urunan krama desa, bantuan pemerintah atau sumber lain yang tidak mengikat dan laba yang ditahan berdasarkan data bulanan tahun 2007 sampai dengan tahun 2011 dalam satuan milyar rupiah.

Data-data yang diperlukan dalam penelitian ini dikumpulkan dengan menggunakan metode dokumentasi yaitu melalui pencatatan berbagai dokumen yang ada pada Bank BPD Bangli dan PLPDK Bangli serta publikasi lainnya termasuk dari internet.

Teknik analisis data yang digunakan dalam penelitian ini adalah analisis kuantitatif yaitu analisis regresi linier berganda. Analisis tersebut dapat dihitung dengan alat bantu komputer yaitu SPSS Versi 15.0 For Windows. Model regresi linier berganda yang digunakan adalah sebagai berikut :

$Y_{t}=\beta_{0}+\beta_{1} X_{1}+\beta_{2} X_{2}+\beta_{3} X_{3}+\mu_{t}$

Keterangan :

$\mathrm{Y}=$ Jumlah kredit yang diberikan

$\mathrm{X}_{1} \quad=$ Tabungan

$\mathrm{X}_{2}=$ Deposito

$\mathrm{X}_{3} \quad=$ Modal LPD

$\beta_{1}-\beta_{3}=$ Koefisien Regresi

$\beta_{0} \quad=$ Intersep

$\mu_{\mathrm{t}}=$ Faktor kesalahan atau gangguan stokhastik

\section{HASIL DAN PEMBAHASAN}

Berdasarkan rangkuman hasil analisis data yang terdapat pada Tabel 3.1 maka dapat diperoleh persamaan regresi sebagai berikut :

$\hat{Y}=-14.661 .370,468+0,735 X_{1}+0,503$

$X_{2}+1,877 X_{3}$ 
Tabel 2 Hasil Penaksiran dengan Model regresi Linear Berganda

\begin{tabular}{lrrrr}
\hline \multicolumn{1}{c}{ Variable Bebas } & \multicolumn{1}{c}{$\begin{array}{c}\text { Koefisien } \\
\text { Regresi }\end{array}$} & $\begin{array}{c}\text { Standar } \\
\text { Error }\end{array}$ & t- hitung & Sig \\
\hline Tabungan & 0,735 & 0,222 & 3,315 & 0,002 \\
Deposito & 0,503 & 0,172 & 2,924 & 0,005 \\
Modal & 1,877 & 0,259 & 7,244 & 0,000 \\
\hline Konstanta & - & & & \\
R Square $\left(R^{2}\right)$ & $14.661 .370,468$ & & & \\
F-hitung & 0,988 & & & \\
Sig & 1.479 .761 & & & \\
\hline
\end{tabular}

Pengaruh secara simultan tabungan, deposito dan modal terhadap jumlah kredit yang diberikan LPD

Jumlah tabungan, deposito dan modal secara simultan berpengaruh signifikan terhadap jumlah kredit yang diberikan oleh LPD di kabupaten Bangli. Hasil uji statistik menunjukkan signifikansi pada taraf nyata 5 persen yang ditunjukkan dengan nilai signifikansi sebesar 0,000. Hasil penelitian ini menunjukkan bahwa variabel-variabel yang dimasukkan dalam model secara bersama-sama memberikan pengaruh yang signifikan terhadap jumlah kredit yang diberikan oleh LPD di kabupaten bangli

Nilai koefisien determinasi $\left(R^{2}\right)$ sebesar 0,988 yang menunjukkan bahwa 98,8 persen variasi (naik turunnya) jumlah kredit yang diberikan oleh LPD di kabupaten Bangli dijelaskan oleh variasi tabungan, deposito dan modal LPD, sedangkan sisanya 1,2 persen dijelaskan oleh variabel lain yang tidak dimasukkan dalam model.

Pengaruh secara parsial tabungan dan deposito terhadap jumlah kredit yang diberikan LPD
Nilai estimasi koefisien tabungan $\hat{\beta}_{i}=0,735$ memiliki arti jika tabungan meningkat sebesar satu milyar maka jumlah kredit yang diberikan oleh LPD di kabupaten Bangli mengalami peningkatan sebesar Rp 0,735 milyar dengan asumsi jumlah deposito dan modal LPD konstan, begitu juga berlaku sebaliknya. Hasil uji statistik menujukkan bahwa tabungan berpengaruh positif dan signifikan pada taraf nyata 5 persen.

Nilai estimasi koefisien deposito $\hat{\beta}_{i}=0,503$ memiliki arti jika deposito meningkat sebesar satu milyar maka jumlah kredit yang diberikan oleh LPD di kabupaten Bangli mengalami peningkatan sebesar Rp 0,503 milyar dengan asumsi jumlah tabungan dan modal LPD konstan, begitu juga berlaku sebaliknya. Hasil uji statistik menujukkan bahwa deposito berpengaruh positif dan signifikan pada taraf nyata 5 persen.

Hasil penelitian ini menunjukkan bahwa semakin meningkat dana pihak ketiga secara signifikan akan meningkatkan penyaluran kredit ke masyarakat, begitu pula sebaliknya semakin menurun jumlah dana pihak 
ketiga akan menurunkan penyaluran kredit kepada masyarakat. Hasil penelitian ini sesuai dengan penelitian yang dilakukan oleh Wahyu Dwipyana (2007) yang menunjukkan bahwa dana pihak ketiga mempengaruhi penyaluran kredit yang diberikan oleh bank pemerintah di Indonesia dan penelitian yang dilakukan Sukarti (2007) juga menyatakan bahwa dana pihak ketiga mempengaruhi penyaluran kredit pada PT. Bank pembangunan Daerah Bali. Hasil ini juga mendukung teori yang dikemukan oleh Warjiyo (2005) yang mengatakan bahwa dana yang dihimpun oleh perbankan dari masyarakat akan digunakan untuk pendanaan aktivitas sektor riil melalui penyaluran kredit dan untuk meningkatkan taraf hidup masyarakat banyak seperti yang disebutkan dalam UU No.10 tahun 1998. Hasil ini juga sesuai dengan penelitian sebelumnya yang dilakukan oleh Meydianawathi (2006) dan Harmanta \& Ekananda (2005) yang menunjukkan bahwa peningkatan dana pihak ketiga akan diikuti dengan peningkatan penyaluran volume kredit oleh perbankan.

\section{Pengaruh secara parsial modal terhadap jumlah kredit yang diberikan LPD}

Nilai estimasi koefisien modal $\hat{\beta}_{i}=1,877$ memiliki arti jika modal LPD meningkat sebesar satu milyar maka jumlah kredit yang diberikan oleh LPD di kabupaten Bangli mengalami peningkatan sebesar $\mathrm{Rp}$ 1,788 milyar dengan asumsi jumlah tabungan dan deposito konstan, begitu juga berlaku sebaliknya. Hasil uji statistik menujukkan bahwa modal berpengaruh positif dan signifikan pada taraf nyata 5 persen. Hasil penelitian ini sesuai dengan hasil penelitian yang dilakukan Sukarti (2007) yang menyatakan bahwa modal bank berpengaruh positif dan signifikan terhadap jumlah kredit yang disalurkan PT. Bank BPD Bali.

Pengelolaan modal LPD sangat penting karena fungsi dan peranan modal sangat strategis, khususnya untuk keamanan sebuah LPD. Modal LPD berfungsi untuk fungsi perlindungan, fungsi operasional dan fungsi pengaturan. Sebagian besar aktiva LPD (kredit) dibiayai oleh dana pihak ketiga, sehingga fungsi modal disini adalah memberikan perlindungan kepada pemilik deposito dalam denominasi besar. Dari sisi fungsi ini LPD yang memiliki modal yang lebih besar dianggap lebih memberikan perlindungan kepada nasabah deposan.

\section{Faktor dominan yang mempengaruhi pemberian kredit oleh LPD}

Berdasarkan hasil olahan data menggunakan bantuan SPSS didapatkan nilai koefisien masing-masing variabel bebas. Adapun nilai masing-masing variabel tersebut adalah koefisien tabungan 0,735 , koefisien deposito 0,503 dan koefisien modal LPD sebesar 1,877. Koefisen modal LPD menunjukkan nilai paling tinggi yang mencerminkan bahwa variabel modal adalah faktor yang paling dominan dalam mempengaruhi pemberian kredit oleh LPD di kabupaetn Bangli.

Pada sebuah LPD, pendapatan terbesar adalah pendapatan bunga dari penyaluran kredit. Sehingga hal ini menyebabkan LPD berlomba-lomba meningkatkan penyaluran kreditnya. Semakin banyak menyalurkan kredit

Jurnal IImu Sosial dan Humaniora | 347 
maka semakin banyak pendapatan bunga yang akan diperoleh. Ketika pendapatan yang diterima meningkat nantinya dapat mempengaruhi jumlah laba. Laba yang diperoleh di akhir periode 60 persen akan digunakan sebagai cadangan modal dan sisanya akan digunakan untuk dana pembangunan desa (20 persen), jasa produksi (10 persen), dana pembinaan, pengawasan dan perlindungan (5 persen) dan dana sosial (5 persen). Pembagian laba diporsikan paling besar untuk cadangan modal sehingga hal ini tentu saja meningkatkan pertumbuhan modal LPD dan akhirnya dapat meningkatkan sumber dana untuk menyalurkan kreditnya.

\section{SIMPULAN DAN SARAN SIMPULAN}

Berdasarkan pembahasan yang telah diuraikan pada bab IV maka dapat dibuat simpulan sebagai berikut :

1) Tabungan, deposito dan modal secara simultan berpengaruh signifikan terhadap jumlah kredit yang diberikan oleh LPD di kabupaten Bangli.

2) Tabungan, deposito dan modal secara parsial berpengaruh positif dan signifikan terhadap jumlah kredit yang diberikan oleh LPD di kabupaten Bangli.

3) Faktor yang paling dominan mempengaruhi pemberian kredit oleh LPD di kabupaten Bangli adalah modal LPD.

\section{SARAN}

Berdasarkan simpulan yang telah diuraikan, maka diharapkan pengurus LPD memberikan kemudahan baik dari segi agunan dan kecepatan proses bagi masyarakat (krama) khususnya untuk usaha mikro dan kecil dalam proses perolehan kredit untuk kelangsungan usahanya, tentunya tanpa mengabaikan unsur kehati-hatian.

\section{UCAPAN TERIMA KASIH}

Pertama-tama perkenankanlah kehadapan Ida Sang Hyang Widhi Wasa/Tuhan Yng Maha Esa atas Asung Kerta Wara Nugraha-Nya sehingga penelitian ini dapat diselesaikan. Pada kesempatan ini, perkenankanlah penulis mengucapkan terima kasih yang sebesar-besarnya kepada Lemlit Undiksha, Kepala Bank BPD Cabang Bangli, Ketua PLPDP Propinsi Bali atas dukungan, semangat dan kerjasamanya yang telah memotivasi penulis dalam penyelesaian penelitian ini.

Semoga Ida Sang Hyang Widhi Wasa/Tuhan Yang Maha Esa selalu melimpahkan anugerah-Nya kepada kita semua, serta semua pihak yang telah membanu penulis baik secara langsung maupun tidak langsung

\section{DAFTAR PUSTAKA}

Adhitya. 2011. Pengaruh Dana Pihak, CAR, NPL, ROA dan LDR Terhadap Penyaluran Kredit Pada Bank Umum Di Indonesia (Studi Empiris : Bank yang Terdaftar di BEI). Jurnal. www.google.com

Anonim. 2007. Analisis Respon Suku Bunga dan Kredit Bank di Kalimantan Selatan Terhadap Kebijakan Moneter. Kajian Ekonomi Regional Kalimantan Selatan : BI Banjarmasin www.google.com 
Anonim. 2010. "Suku Bunga Buka Faktor Penentu" Suara Karya. 8 Januari

Aryaningsih. 2008. Pengaruh Suku Bunga, Inflasi, dan Jumlah Penghasilan Terhadap Permintaan Kredit di PT BPD Cabang Pembantu Kediri. Jurnal Penelitian dan Pengembangan Sains \& Humaniora. Edisi April 56-67. Singaraja : Undiksha.

Billy. 2010. Analisis Faktor-faktor yang Mempengaruhi Kebijakan Penyaluran Kredit Perbankan (Studi Pada Bank Umum di Indonesia Periode 2005 - 2009). Jurnal. www.google.com

Candra. 2009. "Faktor-faktor yang Mempenagruhi strategi pemberian kredit dan dampaknya terhadap NPL (studi kasus pada BPR di propinsi Jawa Tengah)" (tesis). Semarang : Unversitas Diponegoro

Chaikal Nuryakin dan Perry Warjiyo. 2006. Perilaku Penawaran Kredit Bank di Indonesia, Kasus Pasar Oligopoli Periode Januari 2001 Juli 2005. Buletin Ekonomi Moneter dan Perbankan. Oktober 2006. www.bi.go.id

Ghozali, Imam. 2006. Aplikasi Analisis Multivariate dengan Program SPSS. Semarang : Badan Penerbitan Universitas Diponegoro

Gujarati, Damodar. 1997. Ekonometrika Dasar. Jakarta : Erlangga

Insukindro. 1995. Ekonomi Uang dan Bank. Teori dan Pengalaman di Indonesia. Yogyakarta: BPFE.

Kasmir. 2004. Bank \& Lembaga Keuangan Lainnya, Edisi Keenam. Jakarta : PT Rajagrafindo Persada
Mandala Manurung. 2004. Uang, Perbankan, dan Ekonomi Moneter (Kajian Kontekstual Indonesia). Jakarta : FE UI

Meydianawathi. 2006. "Analisis Pengaruh Indiaktor Perbankan Terhadap Penawaan Kredit Sektor UMKM Pada Bank Umum dan Dampaknya Terhadap PDB Indonesia" (tesis). Denpasar : Universitas Udayana

Muliaman D.Hadad dkk.. 2004. Model Estimasi Permintaan dan Penawaran Kredit Konsumsi Rumah Tangga di Indonesia. Direktorat Penelitian dan Pengaturan Perbankan. Bank Indonesia. Jakarta : (www.bi.go.id)

Nasution. 1998. Teori Ekonomi Makro. Pendekatan pada perekonomian Indonesia. Jakarta : Djambatan

Nopirin. 2000. Ekonomi Moneter. Edisi Pertama. Yogyakarta : BPFE.

Nurjaya, dkk. 2011. Landasan Teoretik Pengaturan LPD Sebagai Lembaga Keuangan Komunitas Masyarakat Hukum Adat di Bali. Denpasar : Udayana University Press.

Peraturan Daerah Propinsi Bali Nomor 8 Tahun 2002 Tentang Lembaga Perkreditan Desa.

Peraturan Daerah Propinsi Bali Nomor 3 Tahun 2007 Tentang Perubahan Atas Peraturan Daerah Propinsi Bali Nomor 8 Tahun 2002 Tentang Lembaga Perkreditan Desa.

Peraturan Gubernur Bali Nomor 16 Tahun 2008 Tentang Pengurus dan Pengawas Internal Lembaga Perkreditan Desa 
Seandy. 2010. "Analisis Pengaruh CAR, NPL, inflasi, pertumbuhan DPK dan exchange rate terhadap LDR (studi kasus pada bank umum di Indonesia 2004 - 2008)" (skripsi). Semarang : Universitas Diponegoro.

Setyari. 2006. "Analisis Beberapa Variabel yang Mempengaruhi Posisi Fungsi Intermediasi Bankbank Umum di Indonesia" (tesis). Denpasar : Universitas Udayana

Situmorang, Devi R. 2008. Analisis Faktor-faktor yang Mempengaruhi Permintaan Kredit Perbankan di Sumatera Utara. Artikel : www.google.com

Situmorang, Johny W. 2007. Suku Bunga Perbankan Masih Penghambat Pembiayaan UMKM Indonesia. Artikel : www.google.com

Sudirman, I Wayan. 2000. Manajemen Perbankan, Suatu Aplikasi. Denpasar : BP

Sudirman, I Wayan.1996. Manajemen Perbankan, Teori Kebijaksanaan dan Terapan. Denpasar : Badan Usaha FE Unud.
Sugiyono. 2007. Metode Penelitian Bisnis. Bandung : CV Alfabeta

Sukarti. 2007. "Pengaruh Modal, DPK, BI Rate, dan Inflasi Terhadap Kredit yang Disalurkan PT Bank BPD Bali" (tesis). Denpasar : Universitas Udayana

Sukirno, Sadono. 2001. Pengantar Teori Makro Ekonomi Edisi Kedua. Jakarta : PT Raja Grafindo

Undang-undang Republik Indonesia No. 10 Tahun 1998 tentang Perbankan (Perubahan atas Undang-undang No.7 Tahunn 1992)

Wahyu Dwipayana. 2007. "Pengaruh Suku Bunga Kredit, Dana Pihak Ketiga, Tingkat Inflasi dan Kurs terhadap Jumlah Kredit pada Bank Pemerintah di Indonesia 19962005" (tesis). Denpasar : Universitas Udayana

Wirawan, Nata. 2002. Statistik 2 (Statistik Inferensia) Untuk Ekonomi dan Bisnis. Denpasar : Keraras Emas. 